PART 1

The Introduction of Printing in the Asian Context: Wider Perspectives on Print and Manuscript

Cultures 
Peter Burke - 9789004316256

Downloaded from Brill.come4/26/2023 11:47:52AM via free access 


\title{
Three Print Revolutions
}

\author{
Peter Burke
}

In what follows I shall try, very briefly, to compare three print revolutions: in the early modern West, the region that I know best; in Ming China; and finally in Tokugawa Japan, while thinking about a major absence, the early modern Islamic world, despite a famous but abortive experiment in Istanbul in the early eighteenth century. I leave it to a more ambitious scholar to extend the comparative approach and to try to place printing in the context of what the Canadian historian Harold Innis (2008) called the 'bias of communications', especially of writing: on clay tablets, papyrus, parchment and so on, in other words the political and social consequences of using particular media.

To speak of three revolutions already raises at least two major problems: one about comparison and the other about the idea of revolution. Unlike some of my colleagues in plain or general history, I firmly believe in the value of comparison, including the search for differences as well as for similarities or functional equivalents. Under the umbrella of comparative history I also include what the French call histoire croisée, in other words the search for connections, intercontinental as well as international. Some supporters of histoire croisée present themselves as replacing an older comparative history, but in my view the search for similarities and differences on the one hand, and the search for connections on the other, are perfectly compatible and equally necessary (Werner and Zimmermann 2004). This point may be illustrated from the history of printing. Although many western scholars long assumed that printing with moveable type was more efficient than block printing, it has recently been argued that each system had its particular advantages and disadvantages, with block printing being better adapted to a non-alphabetic writing system like the Chinese (Brokaw forthcoming). As for histoire croisée, the possibility that printing with moveable type reached Europe from China or Korea (despite the difficulty of crossing the barrier of the print-less Islamic world) has long been discussed, given what has been called the 'almost hallucinatory similarity' between the two methods (Carter 1931; Martin 1994, 225). At the very least, news about this may have reached the ears of Gutenberg, just as news about a Dutchman having constructed a telescope reached the ears of Galileo a century and a half later. In Galileo's case, once he knew that a telescope existed, he was able to construct one of his own. Might Gutenberg have done the same?

(C) PETER BURKE, 2016 | DOI 10.1163/9789004316256_003

This is an open access chapter distributed under the terms of the Creative Commons Attribution- 
What counts as a 'revolution' has long been a subject of debate among historians, but focussing on the topic of this conference, print as an agent of change, we might say that any innovation that has important consequences counts as revolutionary (Porter and Teich 1986). In the case of western history, Gutenberg's invention, whatever inspired it, has long been viewed in this way. Among the first centenaries to be celebrated were the centenary of printing in 1540 (since it was believed that Gutenberg had printed his first book in 1440), the bicentenary of printing in 1640 and its tercentenary in 1740. The philosophe Condorcet saw print as literally epoch-making - the eighth epoch of his 'Sketch for the History of the Progress of the Human Mind' (1795).

As for the consequences of printing in the West, they are the focus of two major studies, the one by Betty Eisenstein (1979) from which this conference takes its title, and an earlier study in French by Lucien Febvre and Henri-Jean Martin, first published in $195^{8}$ and translated into English under the title The Coming of the Book (1979). Both studies discuss the Renaissance and the Reformation at some length, but Eisenstein adds the Scientific Revolution of the 17th century. Another difference between the two studies is that Eisenstein is aware of the work of the media theorist Marshall McLuhan (a former student of Harold Innis) and tries to domesticate his ideas, notably the idea that 'the medium is the message', translating it into a language that ordinary empiricist historians would understand. There is, of course, a danger of exaggerating the consequences of printing. Eisenstein virtually claims that printing caused the Renaissance, although the movement that we call the revival of classical antiquity was already under way more than a century before Gutenberg opened his shop. Again, in discussing the consequences of print in particular communities at particular moments, one needs to ask how many people were literate. In seventeenth-century Europe, there was enormous variation between Sweden, where almost every man, woman and child could read (though most were unable to write), and Russia, where virtually no one could read except the clergy (Johansson 1973; Marker 1982).

All the same, despite controversies on matters of detail, there is now a sort of consensus among western historians of printing about certain important consequences. It may be useful to distinguish five of these consequences. ${ }^{1}$

1 What follows draws on, criticizes and attempts to refine and develop the remarks on print culture in Eisenstein (1979, 71-129). 
1. In the first place, there is the most obvious consequence. Books became cheaper and more numerous, while both public and private libraries became bigger. By the middle of the sixteenth century, the number of books, especially new publications, was coming to be perceived as frightening or at least as confusing, an early example of what has come to be known as 'information overload' (Blair 2010). The ideas expressed in print were amplified, spreading to more people in more places than before (Eisenstein 1979, 71-80) Unorthodox ideas became more difficult to stamp out, as in the famous case of the Reformation. Martin Luther was far from the first theologian to challenge the Catholic Church. In the early fifteenth century, the Czech reformer Jan Hus had done the same. However, Hus was burned as a heretic in 1415 and his ideas, which had not had time to spread very much beyond Central Europe, were suppressed. The pope would have liked to suppress Luther's ideas in the same way, but by 1521 Luther had published three pamphlets in German, one of which sold 4000 copies in a single day, and these texts were soon translated into Latin. As a result, Luther's ideas became virtually impossible to suppress.

2. A second important consequence of printing stressed by western historians is the preservation of information, allowing it to accumulate, a point already made in the early days of the new invention, among others by the Venetian physician Nicola Gupalatino, writing in the early 1470s, and again by Eisenstein, writing of the "cumulative impact exerted by the new communications system" (Eisenstein 1979, 29, 113-26). Printing in multiple copies was a kind of insurance against the loss of knowledge, a loss (especially in the case of the destruction of the library of Alexandria and the fall of the Roman Empire) of which Renaissance scholars were very much aware (in other words, in the sixteenth century, fear of loss, of too few books, coexisted with fear of overload, of too many books). Again, it has often been argued that the 'scientific revolution' associated with Galileo, Kepler, Newton and others happened in the seventeenth century, and not before, because it had become possible by that time to build theories on data accumulated earlier. The Scientific Revolution was dependent on an earlier 'scientific renaissance' that involved the rediscovery and the publication of classical texts about the world of nature (Boas 1962; Eisenstein 1979, vol. 2, passim).

3. A third consequence of printing was the fixing of what had been variable (Eisenstein 1979, 80-88). This assertion has become the subject of debate, since it turns out that different copies of the same edition of an early 
printed text are far from identical, thanks for instance to the correction of errors in the workshop while printing was in progress. Indeed, it has been argued that "no two final copies out of a given edition would necessarily be the same". This 'instability' has sometimes have been exaggerated but it needs to be remembered, although, relatively speaking, a printed text was more stable and more uniform than different manuscript copies of a text, even if they had been written by the same scribe (Johns 1998, 91, also 10, 31, 172; McKitterick 2003 8-9, 23, 68, 97, 217-30). As a result, it was possible to give more exact references, to page numbers for instance, allowing readers to find the source of a given statement more easily. In that respect the rise of what we now consider to be proper research methods depended on the rise of print.

In any case, the tendency to fixing, to freezing the fluid, affected much more than different copies of a given edition. In the case of language, for instance, thinking now not only of the sixty-odd languages current in sixteenth-century Europe, but also of the numerous dialects of what we call the 'same' language, including dialects that were mutually unintelligible. It was for this reason that Luther chose not to write in his native Saxon variety of German but in a hybrid language that deliberately mixed the language of different regions in order to be understood all over the German-speaking lands. Printers supported this tendency towards standardization because a standard form of language would allow them to sell more copies of a given book. In some cases where the manuscript of a sixteenth-century book has survived as well as the first edition, it is possible to view linguistic standardization at work (examples in Burke 2004, 106-7, and more generally, 89-110).

Another kind of standardization was the effect of the use of printed forms: for sixteenth-century Spanish contracts, for instance, or for Venetian census-takers in the same period (using three separate forms for nobles, citizens and artisans and asking about the numbers of children, servants and gondolas). By the seventeenth century there were even printed forms, in Latin, for the cardinals to use when they elected popes ('Ego ... cardinalis... eligo in summum pontificem Reverendum Dominum meum Dominum cardinalem...') (Burke 1987, 179-80). The same method was used for gathering knowledge. Bruno Latour's claim that the astronomer Tycho Brahe used "pre-printed forms", asking his colleagues elsewhere to enter their observations on the forms and return them to him, appears to be mistaken, but from the mid-seventeenth century onwards, printed questionnaires were in use, helping to standardize answers and thus to make them comparable (Latour 1987, 226-7, criticized in Johns 1998, 13, 17; Fox 2010). 
4. Other possible consequences of print have often been discussed, with less agreement. One point concerns the relation between the rise of scepticism and the increase in the awareness of alternative versions of a given story. A century after Gutenberg, a French gentleman sitting in the library of his chateau, Michel de Montaigne, noted major disagreements between different authors, and this led him to ask whether it was possible to know anything at all. In the seventeenth century, the rise of newspapers, offering the reader a variety of papers presenting contradictory versions of the same story, encouraged this kind of scepticism (Eisenstein 1979, 74; Dooley 1999, 3 and passim; Burke 2000, 197-212.).

5. There remains the question of identity, the construction of communities by print. In early modern Europe, the scholarly community or 'republic of learning' was constructed not only by letter-writing, but also by the circulation of learned books, often published in an international language, Latin. In the nineteenth century, national communities were constructed at least in part by printing in different vernaculars, a point emphasized in a famous, controversial book by Benedict Anderson, who noted the importance for this process of consciousness raising of 'print capitalism' in general and of printed newspapers and maps in particular (Anderson 2006; Bots and Waquet 1997).

It might be prudent for a historian of early modern Europe to stop at this point and allow specialists on other parts of the world to decide whether any of the claims made above are relevant to printed texts outside Europe in their many languages and scripts. To provoke discussion, however, it may be useful to offer a few remarks about two more print revolutions, one in China and the other in Japan.

The example of China has been invoked in order to criticize Eisenstein for "technological determinism" and for a lack of concern with "the way in which print is embedded in society", since only in Europe was print a "powerful agent of change" (Raven 1999, 233, 224n). As Tim Barrett (2008) recently argued, printing is even older in China than was previously thought. All the same, the true print revolution seems to have occurred at much the same time as in Europe, in the long sixteenth century. "From 1400 to 1600 annual imprint production, expressed in terms of decade-by-decade averages of new imprint titles, increased as much as twenty-fold" (McDermott forthcoming). Commercial printing expanded in some regions in particular, especially the Jiangnan or lower Yangtze delta. Introducing China into the discussion widens it in important ways. On the production side, it is illuminating to compare and contrast block printing with printing with moveable type. Western historians used to think that moveable type was simply superior; then they realized that 
the problem of printing a language written in ideograms needs a different solution from a language written in an alphabet; and now they see that the two systems have different costs and benefits (Brokaw forthcoming). On the side of the readers, the time taken to learn 20,000 or 30,000 characters meant that serious literacy was restricted to a small elite, the examination candidates for whom so many books were written (though western schoolboys were also an important captive audience for textbooks). However, "semi-literacy", in other words the knowledge of some 2000 or 3000 characters, was more widespread and must not be forgotten (Rawski 1979). The sheer size of the Chinese market for print seems extraordinary for a western historian who takes for granted a variety of languages impeding the flow of information. On the other hand, the diversity of political regimes in Europe also impeded the effective censorship of literature that was considered subversive for religious or political reasons. The importance of frontier zones such as the Netherlands and Switzerland in the smuggling to France of unorthodox political and religious books (known euphemistically as 'philosophical books') has been discussed by scholars such as Elizabeth Eisenstein (1992) and Robert Darnton (1995).

Turning now to Japan, the print revolution, or perhaps one should say print's commercial revolution, came a generation or two after China, in the early seventeenth century, and indeed came from China, offering an important example of 'connected history'. The speedy success of the new medium was linked to the rapid urbanization of the country at this time, especially the growth of three cities, Kyōto, Ōsaka and the new capital of Edō. It was also linked to the coexistence of printing in Chinese characters with printing in a syllabic script that ordinary people, male and female, could learn quickly. Turning to consequences, Mary Elizabeth Berry, making a creative use of Benedict Anderson's book, has recently and persuasively argued for the link between what she calls the print-driven 'information revolution' at this time and the rise of national consciousness in Japan (Berry 2006).

To conclude, two further general points may be worth making. The first concerns the term 'agent'. Can print be an agent of change? Yes and no. In some ways it is surely less misleading to think about people as agents rather than about things. It was not the printing press, but the printers, some of whom (the 'ideologists', one might call them, such as Melchior Lotter and Hans Lufft, who supported Luther as well as printing his work) wanted to change the ideas of readers, while others (let us call them 'the mercenaries') concentrated on making a profit and might print books for Catholics and Protestants alike (Cole 1984). On the other hand, some of the consequences of print were unintended, and in that sense the medium may be regarded as an agent. It remains necessary to ask, what are the circumstances that allow print to become an effective 
agent of change, especially in some places and at some periods? A second and final point is that, as a European historian of Europe, I have found that reading about the diverse careers of print in China and Japan has helped me to understand what was happening at home by revealing roads that were not taken. Comparison makes us more aware of possible alternatives and provokes the search for explanations. I hope that the same goes for specialists in Tibetan and the other languages discussed at this conference.

\section{References}

Anderson, Benedict. 2006 (1983). Imagined Communities: reflections on the origin and spread of nationalism. London: Verso.

Barrett, Timothy H. 2008. The Woman Who Discovered Printing. New Haven, ст: Yale University Press.

Berry, Mary Elizabeth. 2006. Japan in Print: information and nation in the early modern period. Berkeley, CA: University of California Press.

Blair, Ann. 2010. Too Much to Know: managing scholarly information before the modern age. New Haven, ст: Yale University Press.

Boas, Marie. 1962. The Scientific Renaissance, 1450-1630. London: Collins.

Bots, Hans and Françoise Waquet. 1997. La République des lettres. Paris: Belin-De Boeck.

Brokaw, Cynthia. Forthcoming. "Empire of Texts: Book Production, Book Distribution, and Book Culture in Late Imperial China". In Book Worlds, East and West, edited by Joseph McDermott and Peter Burke. Hong Kong: Hong Kong University Press.

Burke, Peter. 1987. Historical Anthropology of Early Modern Italy: essays on perception and communication. Cambridge: Cambridge University Press.

— 2000. A Social History of Knowledge from Gutenberg to Diderot. Cambridge: Polity Press.

2004. Languages and Communities in Early Modern Europe. Cambridge: Cambridge University Press.

Carter, Thomas F. 1931. The Invention of Printing in China and its Spread Westward. New York: Columbia University Press.

Cole, Richard G. 1984. "Reformation Printers: Unsung Heroes." Sixteenth-Century Journal 15, 327-39.

Condorcet, Marquis de. 1933. Esquisse d'un tableau historique des progrès de l'esprit humain. 1795. Paris: Bivin.

Darnton, Robert. 1995. The Forbidden Best-Sellers of Pre-revolutionary France. New York: Norton.

Dooley, Brendan. 1999. The Social History of Scepticism: experience and doubt in early modern culture. Baltimore, MD: Johns Hopkins University Press. 
Eisenstein, Elizabeth. 1979. The Printing Press as an Agent of Change. 2 vols. Cambridge: Cambridge University Press.

1992. Grub Street abroad: aspects of the French cosmopolitan press from the age of Louis XIV to the French Revolution. Oxford: Clarendon Press.

2002. "An Unacknowledged Revolution Revisited." American Historical Review 107: 87-105.

Febvre, Lucien and Henri-Jean Martin. 1976 (1958). The Coming of the Book: the impact of printing, 1450-180o. London: New Left Books.

Fox, Adam. 2010. "Printed Questionnaires, Research Networks and the Discovery of the British Isles, 1650-180o." Historical Journal 53, 593-621.

Innis, Harold A. 2008 (1951). The Bias of Communication. Toronto: University of Toronto Press.

Johansson, Egil. 1973. "Literacy Studies in Sweden: some examples." In Literacy and Society in a Historical Perspective, edited by Egil Johansson, 41-65. Umeå: Educational Reports vol. 2.

Johns, Adrian. 1998. The Nature of the Book: Print and Knowledge in the Making. Chicago, IL: University of Chicago Press.

2002. "How to Acknowledge a Revolution." American Historical Review 107: 106-25.

Latour, Bruno. 1987. Science in Action. How to follow Scientists and Engineers through Society. Milton Keynes: Open University Press.

McDermott, Joseph. Forthcoming. "'Non-Commercial' Private Publishing in Late Imperial China." In Book Worlds, East and West, edited by Joseph McDermott and Peter Burke. Hong Kong: Hong Kong University Press.

McKitterick, David. 2003. Print, Manuscript and the Search for Order, 1450-1830. Cambridge: Cambridge University Press.

Marker, Gary. 1982. "Russia and the 'Printing Revolution': notes and observations." Slavic Review 41: 266-83.

Martin, Henri-Jean. 1994 (1988). The History and Power of Writing. Chicago, IL: University of Chicago Press.

Porter, Roy, and Mikuláš Teich, eds. 1986. Revolution in History. Cambridge: Cambridge University Press.

Raven, Diederick. 1999. "Elizabeth Eisenstein and the Impact of Printing." European Journal of History 6: 223-34.

Rawski, Evelyn S. 1979. Education and popular literacy in Ch'ing China. Ann Arbor (MI): University of Michigan Press.

Werner, Michael and Bénédicte Zimmermann, eds. 2004. De la comparaison à l'histoire croisée. Paris: Seuil. 